\title{
Exposure to the Earned Income Tax Credit in Early Childhood and Family Wealth
}

\author{
KATHERINE MICHELMORE AND LEONARD M. LOPOO
}

Using the Panel Study of Income Dynamics and a cohort of individuals born between 2000 and 2011, we examine whether exposure to the Earned Income Tax Credit (EITC) in early childhood (birth to age five) affects family wealth in middle childhood (ages six through eleven). Results suggest that a \$1,000 increase in EITC exposure in early childhood increases overall family wealth in middle childhood by around 4 percent. We also observe an increase in credit card debt ( 3 to 4 percent) and evidence that the EITC increases lowincome families' position in the wealth distribution. Effects are concentrated among white families; we find little evidence of a significant effect of the EITC on the wealth held by black families. Together, these results imply that although the EITC does appear to increase family wealth in childhood, it may not do much to reduce the substantial wealth gap between black and white families.

Keywords: Earned Income Tax Credit, wealth

Started in 1975, the Earned Income Tax Credit (EITC) is currently one of the largest social welfare programs in the United States. According. to the Internal Revenue Service, in 2018, around twenty-five million U.S. households received approximately $\$ 63$ billion in benefits (IRS 2020). Given the large investment in the EITC over the past forty-five years and the substantial number of beneficiaries, the EITC has received considerable attention. Scholars have shown that the EITC directly affects families by increasing the labor-force participation of single mothers (Eissa and Liebman 1996; Meyer and Rosen- baum 2001) and by reducing poverty (Hoynes and Patel 2018). The EITC has also been shown to improve a number of outcomes for children (Hoynes, Miller, and Simon 2015; Dahl and Lochner 2012, 2017), and that these effects persist into adulthood. Evidence suggests, for instance, that EITC exposure in childhood increases educational attainment in adulthood (Bastian and Michelmore 2018; Manoli and Turner 2018) and leads to delays in fertility and marriage among women in early adulthood (Michelmore and Lopoo 2019).

Research indicates that the EITC increases

Katherine Michelmore is assistant professor of public administration at the Maxwell School, Syracuse University, United States. Leonard M. Lopoo is Maxwell Advisory Board Professor of Public Policy at the Maxwell School, Syracuse University, United States.

(C) 2021 Russell Sage Foundation. Michelmore, Katherine, and Leonard M. Lopoo. 2021. “Exposure to the Earned Income Tax Credit in Early Childhood and Family Wealth." RSF: The Russell Sage Foundation Journal of the Social Sciences 7(3): 196-215. DOI: 10.7758/RSF.2021.7.3.09. Direct correspondence to: Katherine Michelmore at kmmichel@syr.edu, 426 Eggers Hall, Syracuse, NY 13244, United States; and Leonard M. Lopoo at Imlopoo @maxwell.syr.edu, 426 Eggers Hall, Syracuse, NY 13244, United States.

Open Access Policy: RSF: The Russell Sage Foundation Journal of the Social Sciences is an open access journal. This article is published under a Creative Commons Attribution-NonCommercial-NoDerivs 3.0 Unported License. 
family income (Dahl, DeLeire, and Schwabish 2011; Hoynes and Patel 2018), but less is known about how it affects families' ability to accumulate wealth. This is surprising given the many reasons the EITC may affect wealth. The lumpsum nature of the credit could allow families to accumulate savings more easily than a monthly or weekly benefit distribution (Sykes et al. 2015). Additionally, because the EITC has been shown to increase labor supply, particularly among single mothers (see, for example, Eissa and Liebman 1996; Meyer and Rosenbaum 2001; Bastian 2019), employment and earnings gains could also lead to more wealth, through increased savings, access to employersponsored retirement accounts, and increases in home equity.

This topic is particularly important to consider at this time, given that wealth inequality has been increasing for decades: although the top 20 percent of the income distribution holds more than 60 percent of all income in the United States, the top quintile of the wealth distribution holds nearly 90 percent (Leiserson, McGrew, and Kopparam 2019). Households with children experience particularly high levels of wealth inequality (Gibson-Davis and Percheski 2018). Our current policies affect income, but wealth and wealth inequality also have important implications for children's outcomes in adulthood, such as college attendance and completion (Lovenheim 2011), marriage and family formation (Addo 2014; Schneider 2011), and the intergenerational transmission of poverty.

This article adds to the EITC literature by asking whether the program affects family wealth and wealth inequality. ${ }^{1}$ Using policy variation in EITC exposure in early childhood (birth year until the year a child turns five) generated by federal and state policy changes that occurred differentially by family size over time, we test whether the EITC affects wealth accumulation in middle childhood (ages six through eleven). Given the large wealth differences be- tween black and white families in the United States, we also investigate whether the EITC affects the racial wealth gap. Using the Panel Study of Income Dynamics (PSID) and cohorts of children born between 2000 and 2011, our findings suggest that the EITC increases family wealth, particularly by increasing checking and savings accounts, retirement savings, and home equity. We also find evidence that the EITC increases one's percentile in the wealth distribution, particularly among the leasteducated households, which has implications for overall wealth inequality. Although these benefits are positive, the EITC also increases credit card debt, which we infer is driven by increased access to credit among low-income households. Additionally, we find that the EITC increases savings among white families but has no significant effect on the wealth of black families, despite higher EITC-eligibility rates among black children compared to white children. This suggests that the EITC could increase wealth inequality between black and white families by increasing wealth among white families but having no significant effect on the wealth of black families.

\section{B ACKGROUND}

The EITC was established in 1975 as a temporary tax credit intended to offset payroll taxes among low-income families. Since its inception, it has been expanded a number of times: it was made permanent in 1978 and has been increased several times, providing a larger credit for families with two or more children beginning in 1991 and for households with at least three children in 2009. It is indexed to inflation and in 2018 was worth up to $\$ 6,431$ for households with at least three children.

In addition to the federal credit, several states have implemented their own EITCs, which piggyback on the federal credit. Most states structure their EITC as a fixed percentage of the federal EITC, such that families eligible for the federal benefit are also typically eligible

1. We focus our analysis on the EITC because it is one of the largest cash transfer programs for low-income households. An examination of the Child Tax Credit (CTC), which has grown in generosity over the last two decades, is beyond the scope of this article. Over much of the period we analyze, the CTC is not available to households with earnings below $\$ 2,500$ and extends much further into the income distribution than the EITC. We view the target audience as substantially different from that of the EITC, and worthy of separate analysis. 
Figure 1. Kernel Density of EITC Exposure, by Birth Cohort

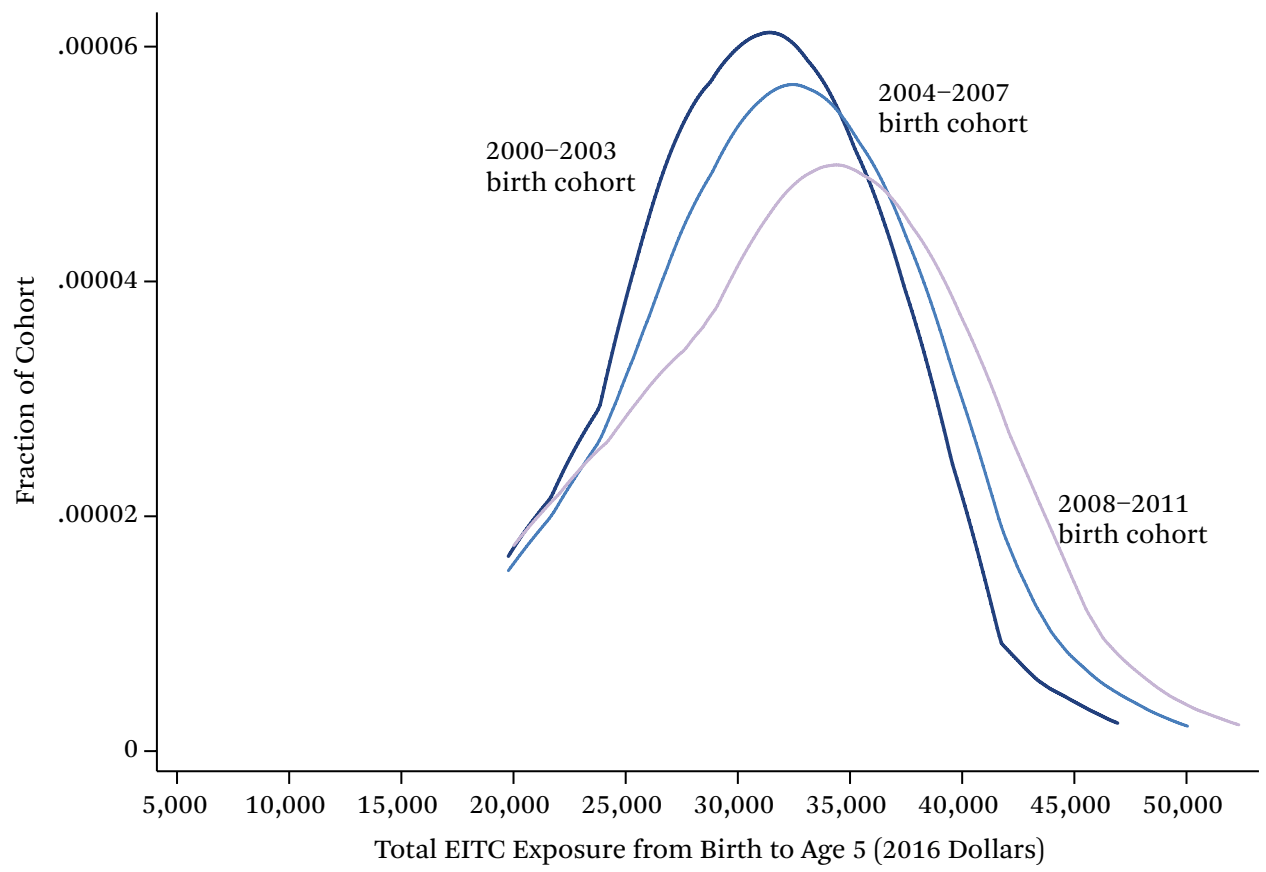

Source: Authors' tabulation based on the Panel Study of Income Dynamics.

Note: Birth cohorts 2000 to 2011. All dollars measured in 2016 terms. Average exposure for 20002003 birth cohort: $\$ 30,371(S D=\$ 5,512)$, for $2004-2007$ cohort: $\$ 31,719(S D=\$ 5,990)$, and for 20082011 cohort: $\$ 32,591(\mathrm{SD}=\$ 7,013)$.

for the state benefit. States vary in when they implemented their EITCs, from Rhode Island in 1986 to Hawaii in $2017 .{ }^{2}$ States also vary in the generosity of their credits, ranging from 3.5 percent to 85 percent of the federal EITC for some families. Many states have also changed the size of their credits over time, most increasing their generosity, but some reducing or eliminating their EITCs altogether. The majority of states fund their EITCs using federal block grant funds from Temporary Assistance to Needy Families (TANF).

Together, the federal and state variation in the EITC over the last few decades provides ample variation in the amount of benefits to which children are exposed, depending on the year and state of birth, as well as the number of children in their families. We illustrate this variation in figure 1, which presents kernel densities of potential EITC exposure between birth and age five for a sample of children born between 2000 and 2011, the sample we focus on in this analysis. We define exposure as the maximum federal and state EITC benefit available in each year, given the number of children residing in the household between a focal child's birth and the year they turn five. ${ }^{3}$ The average child in our sample was exposed to nearly $\$ 32,000$ in potential EITC benefits over this five-year span. The minimum exposure was about $\$ 20,000$, while the maximum exposure was over $\$ 50,000$ (2016 dollars).

Some variation is evident across birth years. Those born between 2000 and 2003 were, on average, exposed to about $\$ 30,000$ in EITC benefits in early childhood, some to as little as $\$ 20,000$, and others to more than $\$ 47,000$. Among those

2. We use data on EITC benefits through the 2016 tax year, which includes California's first year with an EITC, but does not include Hawaii.

3. Some states (California and Minnesota) have different EITC benefit schedules than the federal benefit schedule. For all states, we use the maximum benefit available in the state as a measure of state EITC exposure. 
born between 2004 and 2007, the average exposure increased to approximately $\$ 32,000$, ranging from $\$ 20,000$ to $\$ 50,000$ depending on the state of residence, exact year of birth, and number of children residing in the household. Finally, those born after 2008 were exposed to slightly larger EITC benefits because many states began implementing and expanding their state benefits in the 2010s, and the federal EITC was expanded for households with three or more children in 2009. Among those born between 2008 to 2011, the average exposure in early childhood was $\$ 32,000$, with some children exposed to $\$ 20,000$ and others exposed to as much as $\$ 52,000$. The standard deviation of EITC exposure is nearly $\$ 7,000$.

\section{How Might the EITC Affect Wealth?}

A large body of research finds that expansions to the EITC, particularly in the late 1980s and early 1990s, led to substantial increases in the labor supply of single mothers (Eissa and Liebman 1996; Meyer and Rosenbaum 2001; Hoynes and Patel 2018; Bastian 2019). ${ }^{4}$ These increases also led to positive earnings growth in the short term (Dahl, DeLeire, and Schwabish 2011), and into middle age (Neumark and Shirley 2020). Recent research suggests that, because of the work requirements to obtain the credit, the EITC tends to provide the most benefit to households with income between 50 and 150 percent of the federal poverty threshold (Hoynes and Patel 2018), and during economic downturns, the lowest-earning households may risk losing their benefits altogether (Bitler, Hoynes, and Kuka 2017).

A recent body of work also finds substantial positive effects of the EITC on children's outcomes, ranging from reduced incidence of low infant birthweight (Hoynes, Miller, and Simon 2015), increased childhood test scores (Dahl and Lochner 2012, 2017), reductions in incidents of neglect (Berger et al. 2017), increased educational attainment (Bastian and Michelmore 2018; Manoli and Turner 2018), and reduc- tions in early childbearing (Michelmore and Lopoo 2019).

Although evidence is scant on how the EITC affects overall household wealth, research suggests that the EITC leads to increases in savings (Jones and Michelmore 2018) and reductions in debt (Shaefer, Song, and Shanks 2013). Evidence from qualitative studies and consumption data suggests that recipients use the EITC to pay down debt (Romich and Weisner 2000; Smeeding, Phillips, and O'Conner 2000), purchase large, durable goods (Goodman-Bacon and McGranahan 2008), or save for the future (Sykes et al. 2015; Halpern-Meekin et al. 2015). Much of this work focuses on the contemporaneous effect of the EITC on savings and debt or provides descriptive evidence on how EITC recipients spend their tax refunds. Little is known, however, regarding the longer-term, causal effect of the EITC on household wealth. Further, all of these studies naturally analyze the effect of the EITC on the adult recipients; little is known about how EITC exposure affects the resources available to children, and how exposure to the EITC in early childhood affects family wealth in subsequent years.

The EITC may affect family wealth through a variety of mechanisms. First, the benefit itself is distributed through a lump-sum payment along with a tax filer's annual tax refund. This payment functions as a forced savings mechanism that might allow families to increase savings (Jones and Michelmore 2019) or put a down payment on a house that could increase wealth in the long term. Second, because the EITC has been shown to increase the labor supply of single mothers (Eissa and Liebman 1996; Meyer and Rosenbaum 2001; Bastian 2019), increased earnings may lead to less debt and more savings, particularly if increased employment leads to longer-term earnings growth (Dahl, DeLeire, and Schwabish 2011). Increased employment may increase access to fringe benefits like employer-provided retirement savings accounts such as a $401(\mathrm{k})$ or pension. 
The lump-sum nature of the EITC could also increase debt if households use the EITC to put a down payment on large, durable items such as cars (Goodman-Bacon and McGranahan 2008), furniture, or appliances. If recipients use the EITC to make a down payment on a house, we would expect to find increases in home equity, but also potentially mortgage debt as well. Finally, through their increased work experience, EITC recipients may gain access to more credit, which may increase debt. Additionally, low-income workers may have volatile income and employment, which could lead to increases in debt if they rely on credit to smooth consumption in the presence of income volatility. On the other hand, low-income families are less likely to have access to cheaper forms of credit such as credit cards and thus may be unable to smooth consumption accordingly (Dynarski and Gruber 1997; Baker and Yannelis 2017). In these cases, we may find no association between the EITC and debt accumulation.

The EITC may decrease household wealth through a number of mechanisms as well. Households with asset income greater than $\$ 3,000$ per year are ineligible for the credit. This restriction has been shown to reduce assets held in interest-bearing accounts for filers on the phase-out region of the EITC benefit schedule (Weber 2016), which may lead to reductions in overall wealth for these households.

Beyond the level of family wealth, the EITC could also affect the distribution of wealth across families. It might reduce wealth inequality across households given that it provides a benefit targeted toward low- and moderateincome households. If, on net, these households increase their net worth, we might expect to find an overall reduction in wealth inequality. We would also expect the EITC to affect wealth inequality differently depending on the measure of wealth inequality used: because the EITC predominantly affects families in the bottom half of the income distribution, we may expect to find a narrowing of the gap between the 50th percentile and the 10th percentile of the wealth distribution, but no change in the gap between the 90th and the 50th. In short, the effects of the EITC on wealth are theoretically ambiguous and could have heterogeneous effects.

\section{Data}

To study the relationship between EITC exposure and wealth, we rely on data from the Panel Study of Income Dynamics (PSID). The PSID began in 1968 with a set of approximately 4,800 families. Each year, a representative from each family, called the head of household, was asked a series of employment and demographic questions providing detailed information about the head as well as several other members of the family. The PSID continued to record data annually until 1997, when data collection became biennial. For this project, 2017 was the last year of data available.

The PSID is an ideal data source for this analysis of the EITC and family wealth for several reasons. First, the PSID recorded information not only for adults in the PSID, but also for their children. Because the PSID asks about family wealth during childhood and we can calculate EITC exposure in childhood based on family characteristics, we have a fairly large analytic sample of children with information on their parents to answer our research question. Second, in 1984, the PSID began asking respondents about their wealth. Wealth questions were repeated in 1989, 1994, and starting in 1999, the questions were asked consistently every year data were collected, that is, every other year until 2017. Thus, we have an extensive set of wealth data collected over several years for a large number of families. Finally, because the PSID collects data on the state of residence for the head of household along with information on the number of children in the family, we can construct a measure of potential EITC benefits for each family when the child was young as well as the wealth data measured after EITC exposure.

For this study, we selected all individuals born between 2000 and 2011 who resided with an adult in the PSID study between 2000 and 2017, had a survey weight, ${ }^{5}$ and had nonmissing

5. We created a weight for these children using the average panel weight for the child reported from the year the child was born through the year the child turned five (see Bastian and Michelmore 2018; Michelmore and Lopoo 2019). 
values for the control variables. We use a valueadded model, which requires everyone in our sample to have had a nonmissing wealth measure before the birth of the focal child. Because the PSID began asking the wealth questions more regularly only in 1999, this restricts our sample to those born from 2000 forward. Given these selection criteria, our final analytic sample size was 3,928. We also use the CPI-U-RS to deflate all monetary values to 2016 dollars. Table 1 provides descriptive statistics for the PSID sample.

Table 1. Descriptive Statistics, PSID

\begin{tabular}{lccc}
\hline & Full Sample & White & Black \\
\hline EITC (in thousands) & 31.81 & 31.79 & 31.92 \\
& $(6.23)$ & $(6.21)$ & $(6.52)$ \\
Wealth outcomes & & & \\
Total wealth & 143,736 & 164,482 & 23,439 \\
& $(335,596)$ & $(340,656)$ & $(57,581)$ \\
Percentile in the wealth distribution & 50.11 & 55.5 & 26.55 \\
& $(29.41)$ & $(27.7)$ & $(23.45)$ \\
Checking or savings & 18,298 & 20,789 & 3,694 \\
& $(53,693)$ & $(57,388)$ & $(11,759)$ \\
Stocks & 18,420 & 22,408 & 415 \\
& $(101,320)$ & $(112,579)$ & $(5,443)$ \\
Vehicles & 16,063 & 17,480 & 9,562 \\
& $(18,756)$ & $(19,326)$ & $(12,651)$ \\
Annuity or IRA & 30,251 & 35,666 & 3,376 \\
& $(98,170)$ & $(106,905)$ & $(23,404)$ \\
Home equity & 76,793 & 85,619 & 15,953 \\
& $(179,373)$ & $(159,785)$ & $(40,778)$
\end{tabular}

\section{Debt outcomes ${ }^{a}$}

Credit card debt

Student loans

Medical debt

Legal debt

Family debt

$(1,170)$ 286

$(2,270)$
$(1,120)$ 363

$(3,074)$

\section{Demographic characteristics}

Race-ethnic origin
White
Black
Hispanic
Other race
Female
Year of birth

$\begin{array}{ccc}0.781 & 1 & 0 \\ 0.187 & 0 & 1 \\ 0.023 & 0 & 0 \\ 0.01 & 0 & 0 \\ 0.494 & 0.49 & 0.532 \\ 005.4 & 2,005.4 & 2,005.4 \\ (3.3) & (2.28) & (3.43)\end{array}$


Table 1. (continued)

\begin{tabular}{lccc}
\hline & Full Sample & White & Black \\
\hline $\begin{array}{l}\text { Demographic characteristics (cont.) } \\
\text { Head's education }\end{array}$ & 13.93 & 14.12 & 13.15 \\
& $(2.15)$ & $(2.14)$ & $(1.98)$ \\
Head's age & 33.37 & 32.83 & 35.43 \\
& $(8.88)$ & $(8.07)$ & $(11.36)$ \\
Share of early childhood with married parents & 0.785 & 0.856 & 0.471 \\
Number of children in household (age 0 to 5) & & & \\
One & 0.142 & 0.141 & 0.156 \\
Two & 0.461 & 0.483 & 0.359 \\
Three & 0.253 & 0.25 & 0.267 \\
Four & 0.094 & 0.083 & 0.141 \\
More than four & 0.093 & 0.044 & 0.076 \\
State characteristics & & & \\
Maximum welfare benefit (in thousands) & 4.52 & 4.61 & 4.00 \\
& $(1.763)$ & $(1.7)$ & $(1.82)$ \\
Minimum wage & 7.67 & 7.69 & 7.52 \\
& $(0.916)$ & $(0.923)$ & $(0.883)$ \\
State unemployment rate & 6.72 & 6.65 & 6.88 \\
& $(2.24)$ & $(2.24)$ & $(2.16)$ \\
Number of observations & 3,928 & 2,125 & 1,742 \\
\hline
\end{tabular}

Source: Author's calculations using the Panel Study of Income Dynamics.

Note: Children born between 2000 and 2011. State characteristics come from the University of Kentucky's Center for Poverty Research. All income and wealth measures inflated to 2016 dollars.

a Debt outcomes not assessed in all years. For each debt outcome, sample size for full sample $=3,891$, sample size for white subsample $=2,100$, sample size for black subsample $=1,731$.

\section{Earned Income Tax Credit}

The Earned Income Tax Credit variable measures the aggregate total of the maximum federal and state earned income tax credits possible for the child's family between the year of the child's birth and the year the child turned five, a period we call early childhood. We calculate the maximum EITC credit based on the year, the state of residence for the family, and the number of children in the home. ${ }^{6}$ Variation in the EITC measure, therefore, does not depend on the earnings of the household, but is based on changes in federal and state EITC rules, moves across state lines, and changes in family size. According to table 1, the mean EITC exposure benefit for the family from the year of the child's birth until the year the child turned five was $\$ 31,810$.

\section{Wealth}

The biennial pattern of data collection that started in 1999 creates a few data considerations that we want to balance when using the wealth data. First, because wealth can fluctuate from one year to the next, we calculate the mean wealth for each family over a five-year interval (three panel waves) to create a wealth measure that is less subject to transitory changes in wealth than we might find if we used a measure from a single year. We calculate mean wealth at age six, eight, and ten for those born in odd-numbered years, and at age seven, nine, and eleven for those born in even numbered years. In most cases, we have three wealth measures during that interval, but in some instances as few as one year.

Given the importance of having multiple

6. We follow families in the PSID if they move across state lines. 
years of wealth data, we start our data series for wealth in 1999, the year after which wealth data was collected biennially. These data choices imply that our study will focus on six wealth measures, five of which the PSID collected directly from 1999 to 2017: the total value of checking and savings (mean $=\$ 18,298$ ); the total value of stocks $(\$ 18,420)$; the total value of all vehicles, including vans, trucks, trailers, and boats $(\$ 16,063)$; the total value of any individual retirement accounts (IRAs) or annuities $(\$ 30,251)$; and home equity $(\$ 76,793)$. In addition, we also created a cumulative measure of wealth, which is the sum of checking and savings, stocks, IRAs and annuities, and home equity categories. ${ }^{7}$ Table 1 shows that the mean wealth level in the full sample is $\$ 143,736$.

For comparison purposes, we supply means reported by Fabian Pfeffer and colleagues (2016) from several of the same categories for the PSID (although their data come from 2007 so we inflate to 2016 dollars to make them comparable) in table A1. The average age of the head was fifty in their file. In our sample, the mean age was just over thirty-three, so the families in our analytic sample were younger and had less time to accumulate wealth. As expected, in all instances, the wealth measures in our file are lower than but consistent with those reported by Pfeffer and colleagues. For instance, the reported checking and savings value for all families in the PSID was nearly $\$ 34,000$ for the Pfeffer et al. study and the mean for our sample around $\$ 18,000$. Mean levels for the various wealth categories range from $\$ 16,000$ for vehicles to over $\$ 77,000$ in home equity. For our analyses, we also created a wealth inequality measure defined as the family's percentile of wealth in the overall wealth distribution. ${ }^{8}$ Unsurprisingly, the mean percentile for this wealth measure is the median.

Beginning in 2011, the PSID began to collect data on credit card debt, student loan debt, medical debt, debt to other family members, and legal debt. ${ }^{9}$ In supplemental analyses, we estimate the relationship between EITC benefits and these additional measures. The sample size for the models of these outcomes is 3,891 observations.

The second and third columns of table 1 show considerable differences in wealth between white and black families in the PSID. We ran t-tests, and found statistically significant differences for all of the wealth categories (overall wealth, checking or savings, stocks, vehicles, retirement income, and home equity) as well as the credit card and family debt categories $\left(p<.01\right.$ in all instances).$^{10}$ The mean white family has around $\$ 165,000$ in wealth relative to $\$ 23,439$ for black families. We also find big differences in their position in the wealth distribution, where the mean white family is at the 55th percentile relative to the 27 th percentile for black families. White families had about $\$ 17,000$ more in checking and savings, around $\$ 22,000$ more in stocks, vehicles worth $\$ 8,000$ more, retirement assets of about \$32,000 more, and home equity that was $\$ 70,000$ higher than black families. White families did have higher credit card debt, around $\$ 3,000$ more, and debt to families (approximately \$350) as well. These statistics show considerable differences in the wealth accumulation between black and white families with young children.

7. Following Edward Wolff $(2016,2017)$, we do not include the value of vehicles in the total wealth calculation because its consumption value is usually greater than its resale value.

8. We also created a wealth inequality measure defined as the position in the wealth distribution for a person's birth cohort. The correlation between the overall wealth inequality measure that we used and this cohort wealth measure was nearly 0.99 , and preliminary results using this cohort measure, not surprisingly, were nearly identical to those we report.

9. In 2013, the PSID added farm assets and debt, other real estate assets and debt, and "other debt" as additional wealth measures. Given that these categories do not apply to most families and are available for only three waves, we chose not to include them in our analyses.

10. Only the tests for the difference in student loan, medical, and legal debt were not statistically significant. 


\section{EMPIRICAL STRATEGY}

To estimate the effect of EITC exposure in early childhood on family wealth in middle childhood, we use models of the following form:

$$
\begin{aligned}
Y_{i s t}= & \beta_{0}+\beta_{1} \operatorname{maxEITC05} 5_{i s t}+\beta_{2} X_{i s t} \\
& +\beta_{3} Z_{s t}+\alpha_{s}+\gamma_{t}+\varepsilon_{i s t},
\end{aligned}
$$

where $Y_{\text {ist }}$ represents our outcome of interest, the average family wealth (total wealth, savings, wealth percentile, stocks, vehicles, pensions, and home equity) or debt (credit card debt, student loans, medical debt, legal debt, and family debt) when the child is in middle childhood (either six to ten or seven to eleven years old, depending on the birth year). We estimate this as a function of EITC exposure in early childhood (from birth to age five), $\max E I T C 05_{i s t}$, which we calculate as the sum of the maximum federal and state EITC a child's family could receive each year between the focal child's birth until the year they turn five, based on the year, state of residence, and number of children in the household each year. Our parameter of interest is $\beta_{1}$, which represents the effect of a $\$ 1,000$ increase in EITC exposure from birth to age five on family wealth or debt when a child is in middle childhood.

We control for a number of demographic characteristics $\left(Y_{i s t}\right)$, including gender and race of the child. In addition, we include controls for the head's age in the year the child was born and the maximum education level reported for the head between the child's year of birth and the year of the child's fifth birthday. The marital status variable is the proportion of the period between the year of the child's birth and the year the child turned five that the head was married. We also add controls for the proportion of the time the child lived in a household with one, two, three, and four other children (more than four is the omitted category).

In addition, we include a number of control variables measured at the state level $\left(Z_{s t}\right)$, all measured in the year the child turned five. First, we use the state unemployment rate to capture the state of the business cycle just prior to the wealth calculation. Next, we use the maximum TANF benefit for a family of three to measure the generosity of the state. Our final measure is the state minimum wage, which suggests the minimum value of labor-force participation in the absence of the EITC in the state.

Finally, in all models, we add state of birth fixed effects, year of birth fixed effects, and state-specific year of birth time trends. State fixed effects account for fixed differences across states that may be correlated with EITC generosity and household wealth. Year of birth fixed effects control for national trends that may affect family wealth over time. State-specific time trends control for differential trends in family wealth across states.

With all controls in the model, variation in EITC exposure stems from three sources: within-state changes to EITC generosity over time driven by the implementation and expansion of state EITCs, cross-state differences in EITC generosity at a single point in time, and differences in EITC generosity by family size over time. If we assume that no unobserved factors are correlated with both EITC generosity and family wealth in middle childhood, this model will produce unbiased estimates of the effect of EITC exposure. However, we would have omitted variable bias concerns if, for example, states implemented other policies at the same time as state EITC changes that also affected family wealth. Our controls for other state factors and state-specific time trends should account for the conditions of the state at the time of state EITC implementation and expansions.

In addition to the model described (which we refer to as model 1), we also report results from models including a pre-birth wealth variable measured in the year (or two years depending on the birth cohort) before the birth. This value-added model shows the effect of EITC exposure in early childhood, controlling for the wealth of the family immediately before the child's birth. Coefficient estimates from this model should be less subject to omitted variable bias than those reported in model 1 because any omitted factor correlated with EITC exposure and middle childhood wealth but that also affects pre-birth wealth should be absorbed by the pre-birth wealth coefficient. We report results from this specification as model 2.

As demonstrated earlier, differences in wealth between black and white families in the 
PSID are large. In addition to the described models, we also investigate a possible different effect of EITC exposure in early childhood for black and white families in the PSID by conducting some models separately for black and white children. ${ }^{11}$

\section{RESULTS}

The first column of table 2 (model 1) presents results for overall wealth; the individual wealth variables, available from 1999 to 2017; and the percentile in the wealth distribution (wealth inequality) measure. Each cell entry represents the results from a different model. For each outcome, we present the coefficient on the EITC exposure term, the standard error on the estimate in parentheses, and the percentage change in the mean wealth value into which that coefficient translates in brackets.

The first row suggests that EITC benefits are positively related to overall wealth in middle childhood: a \$1,000 increase in EITC benefits is associated with a $\$ 7,251$ increase (or about a 5.0 percent increase at the mean) in wealth. Additional analyses suggest that the increase in wealth comes from three sources: growth in checking or savings, retirement savings, and home equity. Our results show that a $\$ 1,000$ increase in EITC benefits is associated with a $\$ 1,055$ increase (5.8 percent) in checking or savings, a \$1,544 increase in retirement savings (5.1 percent), and a $\$ 4,539$ increase (5.9 percent) in home equity. None of the point estimates for the remaining wealth categories is statistically significant.

The final row also suggests that EITC exposure increases one's position in the wealth distribution. A \$1,000 increase is associated with a 0.48 percentile-point change in one's position in the wealth distribution. Given that a standard deviation change is around $\$ 6,230$, this represents about a three unit (percentile) increase in position in the wealth distribution.

In model 2, we add the pre-birth wealth measure, which should reduce potential omitted variable bias in the EITC exposure coefficient estimate, as any omitted factor that is related to both the wealth outcome and the EITC exposure variable also likely affected the pre-birth wealth measure. Not surprisingly, the pre-birth wealth measure is substantively and statistically significantly related to most of the middle childhood wealth measures (for coefficients, see table A2). For example, every dollar increase in pre-birth wealth in checking and savings increases checking and savings wealth in middle childhood by around $\$ 0.51$. We find large and statistically significant impacts for vehicles (0.23), annuity or IRA (0.56), and home equity $(0.74)$ as well. Only the overall pre-birth wealth variable and the pre-birth stock wealth is unrelated to wealth in middle childhood.

After controlling for pre-birth wealth, we continue to find a large and statistically significant effect of EITC exposure on total wealth, checking and savings, and retirement savings in model 2, and for many other outcomes, the point estimates are similar to those in model 1. This implies little correlation between EITC exposure in early childhood and pre-birth measures of family wealth, which is reassuring because we would not expect pre-birth wealth to be affected by EITC exposure in future years.

A \$1,000 increase in EITC exposure in early childhood increases total wealth by $\$ 6,037$ (4.2 percent). Pre-birth wealth controlled, we continue to find a statistically significant relationship between the EITC and checking and savings in middle childhood. The point-estimate declines slightly to $\$ 734$ (4.0 percent) for a $\$ 1,000$ increase in EITC exposure. The relationship between EITC exposure and stocks and EITC exposure and vehicles remains insignificant. For the annuity-IRA model, a $\$ 1,000$ increase in EITC exposure is related to a $\$ 1,762$ increase in annuity-IRA wealth, a 5.8 percent increase. Pre-birth home equity controlled, the point-estimate for the home equity measure is reduced to $\$ 2,730$ and is no longer statistically significant.

After controlling for pre-birth position in the wealth distribution, we find that a $\$ 1,000$ increase in EITC exposure increases one's percentile rank in the distribution by about 0.35 
Table 2. Effect of EITC Exposure in Early Childhood on Family Wealth in Middle Childhood

\begin{tabular}{|c|c|c|}
\hline & Model 1 & Model 2 \\
\hline Total wealth & $\begin{array}{l}7,251.21^{* *} \\
(2,589.26)\end{array}$ & $\begin{array}{c}6,036.93^{*} \\
(2,430.34)\end{array}$ \\
\hline Pre-birth wealth & {$[5.0 \%]$} & $\begin{array}{l}0.298 \\
(0.23) \\
{[4.2 \%]}\end{array}$ \\
\hline Checking or savings & $\begin{array}{c}1,054.84^{* *} \\
(312.61)\end{array}$ & $\begin{array}{c}733.92^{*} \\
(349.94)\end{array}$ \\
\hline Pre-birth checking or savings & [5.8\%] & $\begin{array}{l}0.514^{* *} \\
(0.183) \\
{[4.0 \%]}\end{array}$ \\
\hline Stocks & $\begin{array}{c}113.25 \\
(767.22)\end{array}$ & $\begin{array}{c}74.98 \\
(782.44)\end{array}$ \\
\hline Pre-birth stocks & {$[0.6 \%]$} & $\begin{array}{l}0.027 \\
(0.031) \\
{[0.4 \%]}\end{array}$ \\
\hline Vehicles & $\begin{array}{c}161.61 \\
(149.94)\end{array}$ & $\begin{array}{c}120.74 \\
(158.57)\end{array}$ \\
\hline Pre-birth vehicles & [1.0\%] & $\begin{array}{l}0.227^{* *} \\
(0.045) \\
{[0.8 \%]}\end{array}$ \\
\hline Annuity or IRA & $\begin{array}{r}1,543.94^{*} \\
(739.01)\end{array}$ & $\begin{array}{r}1,762.33^{* *} \\
(629.245)\end{array}$ \\
\hline Pre-birth annuity & [5.1\%] & $\begin{array}{c}0.564^{* *} \\
(0.164) \\
{[5.8 \%]}\end{array}$ \\
\hline Home equity & $\begin{array}{c}4,539.18^{*} \\
(1,947.15)\end{array}$ & $\begin{array}{c}2,730.28 \\
(1,741.98)\end{array}$ \\
\hline Pre-birth home equity & {$[5.9 \%]$} & $\begin{array}{l}0.743^{* *} \\
(0.082) \\
{[3.6 \%]}\end{array}$ \\
\hline Wealth percentile & $\begin{array}{c}0.478^{* *} \\
(0.148)\end{array}$ & $\begin{array}{l}0.352^{* *} \\
(0.128)\end{array}$ \\
\hline Pre-birth wealth percentile & & $\begin{array}{l}0.302^{* *} \\
(0.024)\end{array}$ \\
\hline Control for pre-birth wealth measure & & $x$ \\
\hline Number of observations & 3,928 & 3,928 \\
\hline
\end{tabular}

Source: Authors' calculations using the Panel Study of Income Dynamics.

Note: Amounts in \$1,000s; early childhood $=0$ to 5; in middle childhood = 6 to 11; children born between 2000 and 2011. Standard errors in parentheses. Percentages (in brackets) are marginal effects based on the mean level for that wealth category. Each model includes controls for the education level and age of the head, the race and sex of the child, the number of children in the household from the child's birth to age five, the proportion of the time between the child's birth and age five the parents were married, state measures for unemployment, the minimum wage, and the maximum TANF benefit for a family of three, state and year fixed effects, and state-specific linear time trends.

${ }^{*} p<.05 ;{ }^{* *} p<.01$ 
Table 3. Effect of EITC Exposure in Early Childhood on Family Debt in Middle Childhood

\begin{tabular}{lc}
\hline Credit card debt & $140.80^{*}$ \\
$(58.24)$ & {$[3.6 \%]$} \\
& 111.55 \\
& $(223.63)$ \\
Student loan debt & {$[1.1 \%]$} \\
& 55.07 \\
& $(141.62)$ \\
Medical loan debt & {$[3.4 \%]$} \\
& 1.62 \\
& $(4.64)$ \\
Legal debt & {$[2.0 \%]$} \\
& -14.04 \\
& $(24.61)$ \\
Family debt & {$[-4.9 \%]$} \\
& 3,891
\end{tabular}

points. Again, a standard deviation change in EITC exposure suggests a marginal effect of around 2.2 percentile points in the wealth distribution. Given this set of results, it appears that after controlling for wealth prior to the child's birth, EITC exposure in early childhood has a large effect on family wealth in middle childhood.

In table 3, we provide results using a set of debt measures available in the PSID beginning in 2011. Because our time series is much shorter, we do not have the data to create a pre-birth wealth measure so report the models without this control. Research by Lauren Jones and Katherine Michelmore (2018) shows that the EITC is positively related to credit card debt.
Our results suggest a similar result. A $\$ 1,000$ increase in EITC benefits is associated with a $\$ 141$ increase (3.6 percent) in credit card debt. None of the other debt categories was statistically significant.

In table 4, we report results for the same models of wealth with pre-birth wealth controls, but conducted separately for white and black children..$^{12}$ Our findings indicate no statistically significant relationships between EITC exposure and wealth for black families. For white families, we find a statistically significant, positive relationship between EITC exposure and checking-savings and annuity wealth. In analyses available on request, we also conducted pooled models that included inter- 
Table 4. Effect of EITC Exposure in Early Childhood on Family Wealth in Middle Childhood, by Race

\begin{tabular}{lcc}
\hline & White & \multicolumn{1}{c}{ Black } \\
\hline Total wealth & $4,504.254$ & -204.847 \\
& $(2,938.299)$ & $(927.44)$ \\
Checking or savings & {$[2.7 \%]$} & {$[-0.9 \%]$} \\
& $1,037.228^{*}$ & -25.81 \\
Stocks & $(460.789)$ & $(185.769)$ \\
& {$[5.0 \%]$} & {$[-0.7 \%]$} \\
Vehicles & -383.263 & 70.482 \\
& $(1,178.622)$ & $(58.685)$ \\
& {$[-1.7 \%]$} & {$[17.9 \%]$} \\
Annuity or IRA & 91.726 & 342.281 \\
& $(169.27)$ & $(193.734)$ \\
Home equity & {$[0.5 \%]$} & {$[3.6 \%]$} \\
& $2,111.311^{*}$ & -590.681 \\
Wealth percentile & $(872.031)$ & $(623.455)$ \\
Number of observations & {$[5.9 \%]$} & {$[-17.4 \%]$} \\
& 846.407 & 241.436 \\
& $(1,234.782)$ & $(357.317)$ \\
& {$[1.0 \%]$} & {$[1.5 \%]$} \\
& 0.313 & 0.201 \\
Sour & $(0.16)$ & $(0.294)$ \\
\end{tabular}

Source: Authors' calculations using the Panel Study of Income Dynamics.

Note: Amounts in $\$ 1,000$ s; early childhood $=0$ to 5 ; in middle childhood $=6$ to 11 ; children born between 2000 and 2011, white and black subsamples only. Standard errors in parentheses below each coefficient estimate. Each model includes controls for the education level and age of the head, the race and sex of the child, the number of children in the household from the child's birth to age five, the proportion of the time between the child's birth and age five the parents were married, state measures for unemployment, the minimum wage, and the maximum TANF benefit for a family of three, state and year fixed effects, state-specific linear time trends, the wealth measure prior to the birth of the child, and an interaction of EITC exposure with an indicator for whether the child is black. Marginal effects for white families calculated based on the main effect of the EITC and the mean value of wealth among white families; marginal effects for black families calculated based on the sum of the main effect and the interaction term and the mean value of wealth among black families. P-value on joint significance test reported in parentheses below the marginal effect for black families.

${ }^{*} p<.05 ;{ }^{* *} p<.01$

action terms for EITC exposure and race, rather than estimating separate models for black and white families. None of the interaction terms was statistically significant, implying no statistically significant differences in the effect of the EITC on the wealth of black and white families.
In a third set of models (also available on request), we ran models of logged wealth-replacing the negative and zero values of wealth with a logged wealth value of zero-and found some positive indications of EITC on wealth for both black and white families. None of the es- 
timates, however, was statistically significant. Together, the results for white families suggest that the EITC has a positive effect on checking and savings, as well as retirement accounts, but inconclusive evidence on how the EITC affects the wealth of black families.

\section{Effects by Educational Attainment}

To investigate the heterogeneous effects of EITC exposure on wealth, and to investigate whether the EITC affects interfamily wealth inequality, we divide the sample into three categories based on the educational attainment of the head of the household. ${ }^{13}$ Specifically, in table 5, we report separate models for households in which the head has a high school diploma or less (column 1); up to fifteen years of education or less, which would include those in the first subsample (column 2); and a bachelor's degree or higher (column 3). For simplicity, in table 5 , we present results from models that include measures of pre-birth wealth outcomes; see table A2 for results with and without these controls. Because the EITC targets low- to moderate-income families, we expect to see a much greater influence on families with lower levels of education. We do not expect to observe effects for those with a college education, and report results for this subsample for comparison purposes. We split the sample by educational attainment, rather than by income, to avoid concerns of endogeneity of family income with respect to the EITC. Household income is likely affected by the EITC itself, making inference on how the EITC affects wealth across the income distribution difficult.

Results of this exercise are consistent with those reported earlier, although many estimates are imprecisely measured, likely because of the smaller sample sizes. We observe evidence of larger effects of the EITC on wealth among families with a less-educated head of household, and no statistically significant ef- fect of the EITC on families with a highly educated head of household. A $\$ 1,000$ increase in EITC exposure when the child is up to five years old is associated with around a $\$ 2,900$ (6.1 percent) increase in total household wealth among families where the head of household has a high school education or less and a \$3,270 (5.2 percent) increase among household heads with less than a college education, and no significant effect among households with a college degree or more.

As in the sample overall, much of the increase in total wealth stems from increases in checking-savings, retirement, and home equity, although the estimates for checking-savings and home equity are not statistically significant after controlling for pre-birth values of these measures. Checking and savings increases were 7.4 percent for families with a high school education or less, 5 percent for those with less than a bachelor's degree, and around 2.9 percent for college graduates (none is statistically significant at conventional levels). For retirement wealth, we find large and statistically significant increases for those with less than a college education-around 10 percent. Interestingly, we find no effects for those with a high school education or less, suggesting that the EITC primarily helps those with some college increase their retirement wealth. This could be driven by better employment opportunities (with access to more fringe benefits like retirement accounts) of those with some college, relative to those with only a high school degree or less. Results for college graduates are also insignificant and much smaller in magnitude. Home equity increases by 3.3 percent for those with a high school education or less and 1.4 percent for those with less than a college education, but neither of the estimates are significant.

Consistent with the increases in overall family wealth, we also observe increases in position in the overall wealth distribution among less-

13. Because labor income is likely endogenous, we use the head's education to divide the socioeconomic (SES) distribution and report results. In some preliminary analyses, we also used the families' labor income to divide the distribution. The results are largely similar to those we report for education. We see larger proportionate effects at the bottom of the distribution, and the EITC seems to move low-SES families up in the wealth distribution. We also see large point estimates in levels (but much smaller proportionately) for the total wealth outcome for high SES families. 
Table 5. Effect of EITC Exposure in Early Childhood on Family Wealth in Middle Childhood by Education of Head of Household

\begin{tabular}{lccc}
\hline & High School or Less & Less Than College & College or More \\
\hline Total wealth & $2,905.01$ & $3,270.76^{*}$ & $9,080.65$ \\
& $(1,660.15)$ & $(1,281.16)$ & $(5,194.39)$ \\
Checking or savings & {$[6.1 \%]$} & {$[5.2 \%]$} & {$[3.1 \%]$} \\
& 659.56 & 550.5 & $1,039.47$ \\
Stocks & $(579.94)$ & $(327.02)$ & $(795.6)$ \\
& {$[7.4 \%]$} & {$[5.0 \%]$} & {$[2.9 \%]$} \\
Vehicles & 54.8 & 245.71 & -652.57 \\
& $(109.18)$ & $(337.07)$ & $(2,540.07)$ \\
Annuity or IRA & {$[0.9 \%]$} & {$[3.1 \%]$} & {$[-1.0 \%]$} \\
& 31.27 & 88.69 & 109.54 \\
Home equity & $(283.48)$ & $(152.42)$ & $(247.61)$ \\
& {$[0.2 \%]$} & {$[0.6 \%]$} & {$[0.5 \%]$} \\
Wealth percentile & -64.67 & $1,026.84^{*}$ & $2,891.18$ \\
& $(349.55)$ & $(451.12)$ & $(1,716.14)$ \\
& {$[1.0 \%]$} & {$[9.9 \%]$} & {$[3.9 \%]$} \\
Number of observations & $1,262.7$ & 665.96 & $5,053.7$ \\
\hline
\end{tabular}

Source: Authors' calculations using the Panel Study of Income Dynamics.

Note: Amounts in $\$ 1,000$ s; early childhood $=0$ to 5 ; in middle childhood $=6$ to 11 ; children born between 2000 and 2011. Standard errors in parentheses. Marginal effects based on the mean level for that wealth category presented in brackets. Each model includes controls for the education level and age of the head, the race and sex of the child, the number of children in the household from the child's birth to age five, the proportion of the time between the child's birth and age five the parents were married, state measures for unemployment, the minimum wage, and the maximum TANF benefit for a family of three, state and year fixed effects, state-specific linear time trends, and a pre-birth control for the wealth outcome of interest.

${ }^{*} p<.05 ;{ }^{* *} p<.01$

educated households. A \$1,000 increase in EITC exposure in early childhood leads to a 0.61 percentile increase in the wealth distribution among household heads with a high school diploma or less, and a 0.46 percentile increase among households with less than a college degree. We find no significant effect of EITC exposure in early childhood on percentile in the wealth distribution among children with a college-educated parent. ${ }^{14}$

\section{CONCLUSION}

Over the last several decades, the EITC has become one of the largest components of the social safety net in the United States. Despite an extensive literature on the effects of the EITC on a variety of outcomes, we know little about its influence on wealth accumulation and how the EITC may affect wealth inequality.

Using the PSID and a cohort of individuals born between 2000 and 2011, we find that the 
EITC increases family wealth, primarily through increases in checking and savings accounts, retirement savings, and home equity. Our results suggest that a $\$ 1,000$ increase in EITC exposure in early childhood (from birth to year of one's fifth birthday) increases family wealth in middle childhood (between ages six and eleven) by around 4 percent.

That the EITC increases the amount of savings held in checking and savings accounts as well as retirement accounts suggests that the EITC increases families' ability to save, both for current and future expenditures. Although substantial evidence suggests that the EITC increases the labor-force participation of single mothers (Eissa and Liebman 1996; Meyer and Rosenbaum 2001; Hoynes and Patel 2018; Bastian 2019), little speaks to the types of employment held by recipients. That we find evidence that the EITC increases retirement savings implies either that families gain access to jobs that offer such fringe benefits, or the EITC is allowing them to save more in retirement accounts that they already held. Finally, our results indicating that EITC exposure increases home equity suggests that the EITC may allow families to purchase homes or increase their home equity by allowing them to pay down their mortgages. This latter finding is consistent with previous research that also finds improvements in housing stability (reduced cost burden, increases in independent living) associated with the EITC (Pilkauskas and Michelmore 2019).

Along with these increases in assets, we also find an increase in credit card debt (3.6 percent) associated with EITC exposure in early childhood. Although determining whether this is necessarily a good or bad outcome is difficult, one interpretation is that the EITC increases access to credit cards. Low- and moderate-income households have less access to credit cards than higher-income households (Jones and Michelmore 2018). By increasing labor supply (Eissa and Liebman 1996; Meyer and Rosenbaum 2001; Bastian 2019) and family income (Hoynes and Patel 2018), the EITC may also increase access to credit. Depending on the counterfactual, increasing access to credit cards could be welfareimproving if households are otherwise forced to rely on high-interest credit such as payday loans.

How this increase in wealth translates to overall wealth inequality is more difficult to answer. All of our estimates are much larger proportionately for less-educated families, which is consistent with the EITC targeting low- and moderate-income families, and provides suggestive evidence that the EITC reduces wealth inequality. More explicitly, we also evaluate how EITC exposure in early childhood affects one's position in the wealth distribution. We find that a standard deviation change in EITC exposure (approximately \$6,230) increases position in the wealth distribution by approximately 2.2 percentiles, effects being particularly large among the least-educated households (4 percentiles). Assuming a fixed wealth distribution, this suggests that the EITC could reduce wealth inequality, given that those at the bottom or near-bottom move up in the wealth distribution. We find no effect of the EITC on percentile in the wealth distribution among collegeeducated households. On the other hand, some of our estimates, such as the increase in retirement savings associated with EITC exposure, appear to be concentrated among those with some college experience. We find little evidence that the EITC increases the retirement savings of those with a high school degree or less. This finding suggests that the EITC may increase economic mobility most for those with moderate skill levels. This is also consistent with earlier research that shows that households with family income between 50 percent and 150 percent of the federal poverty line benefit the most from the EITC (Hoynes and Patel 2018), because households in this income range typically qualify for the largest EITC benefits.

We observe large differences in wealth accumulation between black and white families, but our results do not provide conclusive evidence on how the EITC differentially affects the wealth accumulation of black and white families. We find large point estimates and statistically significant effects of the EITC on the wealth accumulation of white families, but no definitive evidence that the EITC increases the wealth of black families. However, our standard errors are too large to rule out large increases or decreases in the wealth of black families as a result of EITC exposure. These findings provide suggestive evidence that the EITC could exacerbate wealth inequality between black and 
white families by primarily improving the wealth status of low- and moderate-income white families. More research is necessary, preferably including larger samples of nonwhite families, to further understand how the EITC affects racial wealth gaps.

The EITC has an asset limit for recipients: households with more than $\$ 3,000$ in asset income are ineligible for the credit. Although only a small fraction of the would-be EITCeligible population-recent estimates suggest approximately 12 percent (Weber 2016) - to the extent that some households are deterred from savings in income-bearing accounts, these findings may underestimate the effect of the EITC on household wealth. Increasing or eliminating the asset income threshold may result in a larger increase in household wealth associated with the EITC (Weber 2016).
Fundamentally, this research suggests that EITC exposure sets families with children on a different, increased wealth trajectory. One might see considerable differences in family wealth over a longer time and may lead to an entirely different standard of living during middle age and retirement. Further, given the importance of assets and available credit, our results suggest that children may benefit from exposure to the EITC in early childhood in many ways. For instance, research indicates that exogenous shocks to household wealth increase access to higher education (Lovenheim 2011), which is consistent with recent literature showing that the EITC improves educational attainment (Bastian and Michelmore 2018; Manoli and Turner 2018) among those exposed to EITC expansions in childhood.

Table A1. Comparison of Wealth Outcomes

\begin{tabular}{lcc}
\hline & $\begin{array}{c}\text { Pfeffer et al. (2016) } \\
\text { in 2016 Dollars }\end{array}$ & $\begin{array}{c}\text { PSID } \\
\text { Full Sample }\end{array}$ \\
\hline Checking or savings & 33,749 & 18,298 \\
& & $(53,693)$ \\
Stocks & 65,008 & 18,420 \\
Vehicles & 17,043 & $(101,320)$ \\
& & 16,063 \\
Annuity or IRA & 53,745 & $(18,756)$ \\
& & 30,251 \\
Home equity & 135,914 & $(98,170)$ \\
& & 76,793 \\
\end{tabular}

Source: Authors' tabulation based on the Panel Study of Income Dynamics. 
Table A2. Effect of EITC Exposure in Early Childhood on Family Wealth in Middle Childhood, by Educational Attainment of Head of Household

\begin{tabular}{|c|c|c|c|c|c|c|}
\hline & \multicolumn{2}{|c|}{ High School or Less } & \multicolumn{2}{|c|}{ Some College or Less } & \multicolumn{2}{|c|}{ College or More } \\
\hline & Model 1 & Model 2 & Model 1 & Model 2 & Model 1 & Model 2 \\
\hline \multirow[t]{2}{*}{ Total wealth } & $3,039.9$ & $2,905.01$ & $3,392.44^{*}$ & $3,270.76^{*}$ & $10,484.62$ & $9,080.65$ \\
\hline & $(1,770.23)$ & $(1,660.15)$ & $(1,354.39)$ & $(1,281.16)$ & $(7,824.52)$ & $(5,194.39)$ \\
\hline \multirow[t]{2}{*}{ Pre-birth wealth } & & 0.019 & & 0.041 & & $0.638^{*}$ \\
\hline & & $(0.031)$ & & $(0.051)$ & & $(0.243)$ \\
\hline \multirow[t]{2}{*}{ Checking or savings } & 839.17 & 659.56 & 636.05 & 550.5 & $1,456.06^{*}$ & $1,039.47$ \\
\hline & (633.43) & (579.94) & (346.16) & (327.02) & (659.32) & (795.6) \\
\hline \multirow{2}{*}{$\begin{array}{l}\text { Pre-birth checking or } \\
\text { savings }\end{array}$} & & 0.136 & & $0.185^{\star}$ & & $0.646^{*}$ \\
\hline & & $(0.094)$ & & $(0.089)$ & & $(0.251)$ \\
\hline \multirow[t]{2}{*}{ Stocks } & 57.4 & 54.8 & 247.05 & 245.71 & -687.88 & -652.57 \\
\hline & $(110.24)$ & (109.18) & (337.11) & (337.07) & $(2,640.56)$ & $(2,540.07)$ \\
\hline \multirow[t]{2}{*}{ Pre-birth stocks } & & 0.001 & & 0.001 & & 0.083 \\
\hline & & $(0.001)$ & & $(0.002)$ & & $(0.086)$ \\
\hline \multirow[t]{2}{*}{ Vehicles } & -37.88 & 31.27 & 121.81 & 88.69 & 168.23 & 109.54 \\
\hline & (340.88) & (283.48) & (171.09) & (152.42) & (246.6) & (247.61) \\
\hline \multirow[t]{2}{*}{ Pre-birth vehicles } & & $0.238^{* *}$ & & $0.254^{* *}$ & & $0.187^{* *}$ \\
\hline & & $(0.056)$ & & $(0.06)$ & & $(0.054)$ \\
\hline \multirow{2}{*}{ Annuity or IRA } & -36.81 & -64.67 & $1,039.22^{*}$ & $1,026.84^{*}$ & $2,047.08$ & $2,891.18$ \\
\hline & (346.83) & (349.55) & (450.74) & $(451.12)$ & $(2,368.32)$ & $(1,716.14)$ \\
\hline \multirow[t]{2}{*}{ Pre-birth annuity } & & 0.086 & & $0.150^{*}$ & & $0.588^{* *}$ \\
\hline & & $(0.064)$ & & $(0.067)$ & & $(0.181)$ \\
\hline \multirow[t]{2}{*}{ Home equity } & $2,180.14$ & $1,262.7$ & $1,470.13$ & 665.96 & $7,669.35$ & $5,053.7$ \\
\hline & $(1,345.11)$ & (829.06) & (844.97) & (569.77) & $(4641.21)$ & $(3,879.4)$ \\
\hline \multirow[t]{2}{*}{ Pre-birth home equity } & & $0.572^{* *}$ & & $0.556^{* *}$ & & $0.765^{* *}$ \\
\hline & & $(0.113)$ & & $(0.072)$ & & $(0.101)$ \\
\hline \multirow[t]{2}{*}{ Wealth percentile } & 0.696 & 0.614 & $0.565^{* *}$ & $0.461^{*}$ & 0.169 & -0.057 \\
\hline & $(0.359)$ & (0.319) & (0.199) & $(0.176)$ & $(0.262)$ & $(0.247)$ \\
\hline Pre-birth wealth & & $0.251^{* *}$ & & $0.269^{* *}$ & & $0.327^{* *}$ \\
\hline percentile & & $(0.046)$ & & $(0.034)$ & & $(0.051)$ \\
\hline Number of observations & 1,580 & 1,580 & 2,872 & 2,872 & 1,056 & 1,056 \\
\hline
\end{tabular}

Source: Authors' calculations using the Panel Study of Income Dynamics.

Note: Amounts in \$1,000s; early childhood = 0 to 5; in middle childhood = 6 to 11; children born between 2000 and 2011. Standard errors in parentheses. Each model includes controls for the education level and age of the head, the race and sex of the child, the number of children in the household from the child's birth to age five, the proportion of the time between the child's birth and age five the parents were married, state measures for unemployment, the minimum wage, and the maximum TANF benefit for a family of three, state and year fixed effects, and state-specific linear time trends.

${ }^{*} p<.05 ;{ }^{* *} p<.01$ 


\section{REFERENCES}

Addo, Fenaba R. 2014. “Debt, Cohabitation, and Marriage in Young Adulthood." Demography 51(5): 1677-701.

Baker, Ross, and Constantine Yannelis 2017. “Income Changes and Consumption: Evidence from the 2013 Federal Government Shutdown." Review of Economic Dynamics 23: 99-124.

Bastian, Jacob. 2019. "The Rise of Working Mothers and the 1975 Earned Income Tax Credit." American Economic Journal: Economic Policy 12(3): 4475.

Bastian, Jacob, and Katherine Michelmore. 2018. "The Long-Term Impact of the Earned Income Tax Credit on Children's Education and Employment Outcomes." Journal of Labor Economics 36(4): 1127-63.

Berger, Lawrence M., Sarah A. Font, Kristen Shook Slack, and Jane Waldfogel. 2017. "Income and Child Maltreatment in Unmarried Families: Evidence from the Earned Income Tax Credit." Review of Economics of the Household 15(4): 134572.

Bitler, Marianne, Hilary Hoynes, and Elira Kuka. 2017. "Do In-Work Tax Credits Serve as a Safety Net?" Journal of Human Resources 52(2): 319-50.

Dahl, Gordon B., and Lance Lochner. 2012. "The Impact of Family Income on Child Achievement: Evidence from the Earned Income Tax Credit." American Economic Review 102(5): 1927-56.

_. 2017. "The Impact of Family Income on Child Achievement: Evidence from the Earned Income Tax Credit: Reply. American Economic Review 107(2): 629-31.

Dahl, Molly, Thomas DeLeire, and Jonathan Schwabish. 2011. "Estimates of Year-to-Year Volatility in Earnings and in Household Incomes from Administrative, Survey, and Matched Data." Journal of Human Resources 46(4): 750-74.

Dynarski, Susan, and Jonathan Gruber. 1997. "Can Families Smooth Variable Earnings?" Brookings Papers on Economic Activity 28(1): 229-303.

Eissa, Nada, and Jeffrey B. Liebman. 1996. “Labor Supply Response to the Earned Income Tax Credit." Quarterly Journal of Economics 111(2): 605-37.

Gibson-Davis, Christina M., and Christine Percheski. 2018. "Children and the Elderly: Wealth Inequality Among America's Dependents." Demography 55(3): 1009-32.
Goodman-Bacon, Andrew, and Leslie McGranahan. 2008. "How Do EITC Recipients Spend Their Refunds?" Economic Perspectives 32(2): 17-32.

Halpern-Meekin, Sarah, Kathryn Edin, Laura Tach, and Jennifer Sykes. 2015. It's Not Like I'm Poor: How Working Families Make Ends Meet in a PostWelfare World. Berkeley: University of California Press.

Hoynes, Hilary W., Doug Miller, and David Simon. 2015. "Income, the Earned Income Tax Credit, and Infant Health." American Economic Journal: Economic Policy 7(1): 172-211.

Hoynes, Hilary W., and Ankur J. Patel. 2018. “Effective Policy for Reducing Poverty and Inequality? The Earned Income Tax Credit and the Distribution of Income." Journal of Human Resources 53(4): 859-90.

Internal Revenue Service (IRS). 2020. "About EITC." Revised June 29, 2020. Accessed December 8, 2020. https://www.eitc.irs.gov/eitc-central/about -eitc/about-eitc.

Jones, Lauren E., and Katherine Michelmore. 2018. "The Impact of the Earned Income Tax Credit on Household Finances." Journal of Policy Analysis and Management 37(3): 521-45.

_. 2019. “Timing Is Money: Does Lump-Sum Payment of Tax Credits Induce High-Cost Borrowing?" Economic Inquiry 57(3): 1659-74.

Leiserson, Greg, Will McGrew, and Raksha Kopparam. 2019. "The Distribution of Wealth in the United States and the Implications for a Net Worth Tax." Washington, D.C.: Washington Center for Equitable Growth. Accessed December 9, 2020. https://equitablegrowth.org/the-distri bution-of-wealth-in-the-united-states-and -implications-for-a-net-worth-tax.

Lovenheim, Michael F. 2011. “The Effect of Liquid Housing Wealth on College Enrollment." Journal of Labor Economics 29(4): 741-71.

Manoli, Day, and Nicholas Turner. 2018. “Cash-onHand and College Enrollment: Evidence from Population Tax Data and the Earned Income Tax Credit. American Economic Journal: Economic Policy 10(2): 242-71.

Meyer, Bruce D., and Dan T. Rosenbaum. 2001. "Welfare, the Earned Income Tax Credit, and the Labor Supply of Single Mothers." Quarterly Journal of Economics 116(3): 1063-114.

Michelmore, Katherine, and Leonard M. Lopoo. 2019. “The Effect of EITC Exposure in Childhood on 
Marriage and Early Childbearing." Center for Policy Research working paper no. 215. Syracuse, N.Y.: Syracuse University.

Neumark, David, and Peter Shirley. 2020. “The Long-Run Effects of the Earning Income Tax Credit on Women's Labor Market Outcomes." Labour Economics 66. Published online June 26. DOI: 10.1016/j.labeco.2020.101878.

Pfeffer, Fabian T., Robert F. Shoeni, Arthur Kennickell, and Patricia Andreski. 2016. “Measuring Wealth and Wealth Inequality." Journal of Economic and Social Measurement 41(2): 10320.

Pilkauskas, Natasha, and Katherine Michelmore. 2019. “Does the Earned Income Tax Credit Reduce Housing Instability?" Demography 56(4): 1303-26.

Romich, Jennifer, and Thomas Weisner. 2000. "How Families View and Use the EITC: Advance Payment Versus Lump Sum Delivery." National Tax Journal 53(4): 1245-65.

Schneider, Daniel. 2011. "Wealth and the Marital Divide." American Journal of Sociology 117(2): 62767.

Shaefer, H. Luke, Xiaoqing Song, and Trina R. Shanks. 2013. “Do Single Mothers in the United
States use the Earned Income Tax Credit to Reduce Unsecured Debt?" Review of Economics of the Household 11(4): 659-80.

Smeeding, Timothy M., Katherin Ross Phillips, and Michael O'Connor. 2000. “The EITC: Expectation, Knowledge, Use, and Economic and Social Mobility." National Tax Journal 53(4): 1187-209.

Sykes, Jennifer, Katrin Križ, Kathryn Edin, and Sarah Halpern-Meekin. 2015. “Dignity and Dreams: What the Earned Income Tax Credit (EITC) Means to Low-Income Families." American Sociological Review 80(2): 243-67.

Weber, Caroline. 2016. “Does the Earned Income Tax Credit Reduce Saving by Low-Income Households?" National Tax Journal 69(1): 41-76.

Wolff, Edward N. 2016. "Household Wealth Trends in the United States, 1962 to 2013: What Happened over the Great Recession?" RSF: The Russell Sage Foundation Journal of the Social Sciences 2(6): 24-43. DOI: 10.7758/RSF.2016.2 .6.02.

2017. "Household Wealth Trends in the United States, 1962 to 2016: Has Middle Class Wealth Recovered?" NBER working paper no. 24085. Cambridge, Mass.: National Bureau of Economic Research. 